International Journal of

Environmental Research and

Public Health

ISSN 1660-4601

www.mdpi.com/journal/ijerph

Article

\title{
Application of Magnesium Modified Corn Biochar for Phosphorus Removal and Recovery from Swine Wastewater
}

\section{Ci Fang, Tao Zhang *, Ping Li, Rong-feng Jiang and Ying-cai Wang}

Key Laboratory of Plant-Soil Interactions of Ministry of Education, College of Resources and Environmental Sciences, China Agricultural University, Beijing 100193, China;

E-Mails: fangci2012@163.com (C.F.); lipinglina@126.com (P.L.); rfjiang@ cau.edu.cn (R.J.); yingcaiwangcau@gmail.com (Y.W.)

* Author to whom correspondence should be addressed; E-Mail: taozhang@cau.edu.cn;

Tel.: +86-10-6273-1104; Fax: +86-10-6273-1016.

Received: 24 June 2014; in revised form: 1 August 2014 / Accepted: 27 August 2014 /

Published: 5 September 2014

\begin{abstract}
The recycling of lost phosphorus (P) is important in sustainable development. In line with this objective, biochar adsorption is a promising method of $\mathrm{P}$ recovery. Therefore, our study investigates the efficiency and selectivity of magnesium modified corn biochar ( $\mathrm{Mg} /$ biochar) in relation to $\mathrm{P}$ adsorption. It also examines the available $\mathrm{P}$ derived from postsorption $\mathrm{Mg} /$ biochar. $\mathrm{Mg} /$ biochar is rich in magnesium nanoparticles and organic functional groups, and it can adsorb $90 \%$ of the equilibrium amount of $\mathrm{P}$ within $30 \mathrm{~min}$. The $\mathrm{Mg} /$ biochar $\mathrm{P}$ adsorption process is mainly controlled by chemical action. The maximum $\mathrm{P}$ adsorption amount of $\mathrm{Mg} / \mathrm{bioch}$ ar is $239 \mathrm{mg} / \mathrm{g}$. The Langmuir-Freundlich model fits the $\mathrm{P}$ adsorption isotherm best. Thermodynamics calculation shows $\Delta \mathrm{H}>0$, $\Delta \mathrm{G}<0, \Delta \mathrm{S}>0$, and it demonstrates the $\mathrm{P}$ adsorption process is an endothermic, spontaneous, and increasingly disordered. The optimal $\mathrm{pH}$ is 9 . The amounts of $\mathrm{P}$ adsorbed by $\mathrm{Mg} / \mathrm{B} 300, \mathrm{Mg} / \mathrm{B} 450$, and $\mathrm{Mg} / \mathrm{B} 600$ from swine wastewater are lower than that adsorbed from synthetic $\mathrm{P}$ wastewater by $6.6 \%, 4.8 \%$, and $4.2 \%$, respectively. $\mathrm{Mg} / \mathrm{bioch}$ ar is more resistant to $\mathrm{pH}$ and to the influence of coexisting ions than biochar. Finally, postsorption $\mathrm{Mg} / \mathrm{biochar}$ can release $\mathrm{P}$ persistently. The $\mathrm{P}$ release equilibrium concentrations are ordered as follows: $\mathrm{Mg} / \mathrm{B} 600>\mathrm{Mg} / \mathrm{B} 450>\mathrm{Mg} / \mathrm{B} 300$. The postsorption $\mathrm{Mg} / \mathrm{B} 300, \mathrm{Mg} / \mathrm{B} 450$, and $\mathrm{Mg} / \mathrm{B} 600$ can release $3.3 \%, 3.9 \%$, and $4.4 \%$ of the total adsorbed $\mathrm{P}$, respectively, per interval time.
\end{abstract}


Keywords: phosphorus; magnesium modified corn biochar; swine wastewater; nutrient recovery

\section{Introduction}

Intensive pig culture is currently an important part of the modern agricultural economy [1]. However, intensive pig culture plants usually generate a great deal of swine wastewater, which contain high concentrations of phosphorus (P) [2]. If this wastewater is not treated reasonably, it can facilitate mosquito breeding and the spread of bacteria in rural areas, especially if it is exposed to air. As a result, swine wastewater poses a major threat to public health. Environmentally, it does not only lead to the pollution of water eutrophication, but also wastes non-renewable resources [3]. Therefore, the $\mathrm{P}$ resource can be recycled from swine wastewater through innovative technology.

Many such technologies have been developed for various applications, including biological $\mathrm{P}$ uptake, chemical precipitation, electrolysis, and adsorption [2]. Biological $\mathrm{P}$ uptake utilizes polyphosphate-accumulating organisms to capture $\mathrm{P}$ in their cells. However, this method is limited by the lack of carbon sources and the difficulty of culturing pure bacteria [4]. Chemical precipitation has been hindered by its high chemical consumption, low recovery efficiency, and excessive production of chemical sludge [5]. Electrolysis is restricted by the little wastewater treatment capacity and the need to replace electrodes frequently [6,7]. However, recovering $\mathrm{P}$ from wastewater using adsorbents is advantageous over the other methods because of its high efficiency and low consumption [2].

Biochar is a new pollution adsorbent that has received a great deal of attention recently. Many researchers have utilized biochar adsorption for organic contaminants, such as sulfamethoxazole [8], phenanthrene [9], and triazine pesticides [10], and heavy metals, such as lead [11], cadmium [12], and mercury [9].

Thus, biochar adsorption can be used to recover P from wastewater for nutrient recycling. However, the poor efficiency and selectivity of $\mathrm{P}$ adsorption hampers the application of typical biochar. Previous research derived low $\mathrm{P}$ recovery ratios of only 73\% [13] and 37\% [14]. Moreover, the coexisting ions in wastewater, including $\mathrm{Cl}^{-}, \mathrm{NO}_{3}{ }^{-}$, and $\mathrm{HCO}_{3}{ }^{-}$, can reduce the recovery ratio of selective $\mathrm{P}$ adsorption by $4 \%, 11 \%$, and $41 \%$, respectively [13]. Previous studies demonstrated cation modified function adsorbents, such as lanthanum/aluminum-modified zeolite adsorbent [15] and Fe-treated artificial zeolite [16], can enhance the efficiency and selectivity of $\mathrm{P}$ recovery. Cation-modified biochar has been developed recently. Chen et al. [17] loaded $\mathrm{FeCl}_{2}$ and $\mathrm{FeCl}_{3}$ on orange peel biochar to adsorb $1.24 \mathrm{mg} / \mathrm{g}$ of P. Zhang et al. [18] loaded AlOOH on cottonwood biochar and adsorbed $135 \mathrm{mg} / \mathrm{g}$ of P.

The $\mathrm{P}$ from postsorption biochar is recycled as fertilizer to maximize nutrient resources in nutrient cycling. Hale et al. [14] reported that postsorption biochar could release $1.48 \mathrm{mg} / \mathrm{g}$ of reactive $\mathrm{P}$, which was higher than the optimal P content required for plant growth (45-50 mg P/kg). However, the reuse of $\mathrm{P}$ as fertilizer may be affected by some of the cations that modify the biochar. Johnston and Richards [19] reported that the $\mathrm{P}$ in iron phosphates was hardly released and was unavailable for plant growth. Rittmann et al. [20] pointed out that aluminum was toxic to many plants and hardly released $\mathrm{P}$ as 
well. Therefore, the ease of $\mathrm{P}$ release and conduciveness to plant growth are important factors in the selection of cations for further biochar modification.

Magnesium, involved in the chlorophyll formation of plants, is considered as a suitable cation for $\mathrm{P}$ recovery [13,21]. Thus, magnesium modified corn biochar $(\mathrm{Mg} / \mathrm{biochar})$ is prepared in our study. It is then compared with biochar, in terms of characteristics, $\mathrm{P}$ adsorption efficiency, selectivity in swine wastewater, and the available $\mathrm{P}$ of postsorption $\mathrm{Mg} / \mathrm{biochar}$.

\section{Experimental Section}

\subsection{Materials}

Biochar: Ground corn was dipped in deionized water (DI) with a mass-to-volume ratio of 1:3 for $2 \mathrm{~h}$, dried at $110{ }^{\circ} \mathrm{C}$, and then pyrolyzed respectively at $300{ }^{\circ} \mathrm{C}, 450{ }^{\circ} \mathrm{C}$, and $600{ }^{\circ} \mathrm{C}$ in nitrogen gas (limited oxygen) for $3 \mathrm{~h}$ (denoted as B300, B450, and B600, respectively). The pyrolyzed sample was cleaned by DI, dried at $60{ }^{\circ} \mathrm{C}$, sieved through $0.1 \mathrm{~mm}-0.2 \mathrm{~mm}$ mesh, and sealed in a container before use.

$\mathrm{Mg} / \mathrm{biochar}$ : Ground corn was dipped in $\mathrm{MgCl}_{2}$ solution with a mass-to-volume ratio of 1:3 for $2 \mathrm{~h}$, dried at $110{ }^{\circ} \mathrm{C}$, and then pyrolyzed respectively at $300{ }^{\circ} \mathrm{C}, 450{ }^{\circ} \mathrm{C}$, and $600{ }^{\circ} \mathrm{C}$ in nitrogen gas (limited oxygen) for $3 \mathrm{~h}$ (denoted as $\mathrm{Mg} / \mathrm{B} 300, \mathrm{Mg} / \mathrm{B} 450$, and $\mathrm{Mg} / \mathrm{B} 600$, respectively). The pyrolyzed sample was cleaned by DI, dried at $60{ }^{\circ} \mathrm{C}$, sieved through $0.1 \mathrm{~mm}-0.2 \mathrm{~mm}$ mesh, and sealed in a container before use.

Swine wastewater: Raw swine wastewater was collected from a pig plant near Beijing. This wastewater was centrifuged, filtered, and stored in the refrigerator before use. The parameters of the swine wastewater are shown in Table 1.

Table 1. The parameter of swine wastewater.

\begin{tabular}{rlc}
\hline \multicolumn{2}{c}{ Items } & Value \\
\hline \multicolumn{2}{c}{$\mathrm{pH}$} & 7.8 \\
$\mathrm{COD}$ & $\left(\mathrm{mg} \cdot \mathrm{L}^{-1}\right)$ & 11,850 \\
$\mathrm{TN}$ & $\left(\mathrm{mg} \cdot \mathrm{L}^{-1}\right)$ & 397 \\
$\mathrm{NH}_{4}{ }^{+}-\mathrm{N}$ & $\left(\mathrm{mg} \cdot \mathrm{L}^{-1}\right)$ & 365 \\
$\mathrm{PO}_{4}{ }^{3-}-\mathrm{P}$ & $\left(\mathrm{mg} \cdot \mathrm{L}^{-1}\right)$ & 84 \\
$\mathrm{SS}$ & $\left(\mathrm{mg} \cdot \mathrm{L}^{-1}\right)$ & 482 \\
$\mathrm{Ca}^{2+}$ & $\left(\mathrm{mg} \cdot \mathrm{L}^{-1}\right)$ & 23 \\
$\mathrm{Mg}^{2+}$ & $\left(\mathrm{mg} \cdot \mathrm{L}^{-1}\right)$ & 17 \\
$\mathrm{~K}^{+}$ & $\left(\mathrm{mg} \cdot \mathrm{L}^{-1}\right)$ & 281 \\
$\mathrm{Na}^{+}$ & $\left(\mathrm{mg} \cdot \mathrm{L}^{-1}\right)$ & 58 \\
$\mathrm{Cl}^{-}$ & $\left(\mathrm{mg} \cdot \mathrm{L}^{-1}\right)$ & 84 \\
$\mathrm{SO}_{4}{ }^{2-}$ & $\left(\mathrm{mg} \cdot \mathrm{L}^{-1}\right)$ & 81 \\
\hline
\end{tabular}

\subsection{Methods}

Kinetics adsorption: $0.2 \mathrm{~g}$ of either biochar or $\mathrm{Mg} / \mathrm{bioch}$ ar was mixed with $20 \mathrm{~mL}$ swine wastewater, and then shaken at $200 \mathrm{rpm}$ in $303 \pm 0.5 \mathrm{~K}$. The supernatant was collected after a certain time interval. 
Adsorption isotherm: $0.2 \mathrm{~g}$ of either biochar or $\mathrm{Mg} / \mathrm{bioch}$ ar was mixed with $20 \mathrm{~mL} \mathrm{P}$ solution (swine wastewater mixed with $\mathrm{NaH}_{2} \mathrm{PO}_{4}$ to obtain the initial P concentration of $84 \mathrm{mg} \mathrm{P} / \mathrm{L}-2600 \mathrm{mg} \mathrm{P} / \mathrm{L}$ ), and shaken at $200 \mathrm{rpm}$ for $12 \mathrm{~h}$ at $288 \pm 0.5 \mathrm{~K}, 303 \pm 0.5 \mathrm{~K}$, and $318 \pm 0.5 \mathrm{~K}$.

$\mathrm{pH}$ influence: $0.1 \mathrm{~g}$ of either biochar or $\mathrm{Mg} / \mathrm{biochar}$ was mixed with $20 \mathrm{~mL}$ swine wastewater at an experimental $\mathrm{pH}$ range of $6-10$. The mixture was then shaken at $200 \mathrm{rpm}$ for $12 \mathrm{~h}$ at $303 \pm 0.5 \mathrm{~K}$.

Influence of coexisting ions: $0.1 \mathrm{~g}$ of either biochar or $\mathrm{Mg} / \mathrm{biochar}$ was mixed with $20 \mathrm{~mL}$ swine and synthetic $\mathrm{P}$ wastewater ( $\mathrm{P}$ concentration $84 \mathrm{mg} \mathrm{P} / \mathrm{L}$ ) at a given experimental $\mathrm{pH}$ level of 9 . The mixture was shaken at $200 \mathrm{rpm}$ for $12 \mathrm{~h}$ at $303 \pm 0.5 \mathrm{~K}$.

Continuous extraction: $0.1 \mathrm{~g}$ of either postsorption biochar or postsorption $\mathrm{Mg} / \mathrm{biochar}(0.1 \mathrm{~g}$ of either biochar or $\mathrm{Mg} /$ biochar mixed with $2000 \mathrm{~mL}$ swine wastewater at $303 \pm 0.5 \mathrm{~K}$ for $12 \mathrm{~h}$ ) was combined with $120 \mathrm{~mL}$ DI containing $2 \%$ citric acid (citric acid DI), and shaken at $200 \mathrm{rpm}$ at $303 \pm 0.5 \mathrm{~K}$.

Interval extraction: after continuous extraction, $0.1 \mathrm{~g}$ of either postsorption biochar or postsorption $\mathrm{Mg} /$ biochar was mixed with $120 \mathrm{~mL}$ of freshly replaced citric acid DI, and shaken at $200 \mathrm{rpm}$ at $303 \pm 0.5 \mathrm{~K}$. The supernatant was replaced with fresh extraction solution every $24 \mathrm{~h}$. This interval extraction process was reiterated six times.

\subsection{Analysis}

Biochar and $\mathrm{Mg} /$ biochar were analyzed by $\mathrm{CHN}$ element analyzer (vario EL, Hanau, Germany), Brunauer, Emmett, and Teller Surface Area Analyzer (BET, ASAP 2020, Atlanta, Georgia, USA), Fourier Transform Infrared Spectrometer (FTIR, Magna-IR 750, Washington, Maryland, USA), Transmission Electron Microscope (TEM, JEM-2100F, Tokyo, Japan).

The concentrations of $\mathrm{PO}_{4}{ }^{3-}$-P were measured according to standard methods (APHA, 2012, 4500-PC. vanadomolybdophosphoric acid colorimetric method). All the experiments were repeated 3 times and the average values were calculated.

\section{Results and Discussion}

\subsection{Characterization Analysis}

The characterization analysis demonstrated that an increase in the pyrolysis temperature of $\mathrm{Mg} /$ biochar and biochar induced a decrease in yield, an increase in carbon (C) content, a decrease in hydrogen $(\mathrm{H})$ content, and an increase in BET surface area. However, nitrogen $(\mathrm{N})$ content did not change significantly. Moreover, $\mathrm{Mg} / \mathrm{biochar}$ contained numerous magnesium nanoparticles. Both $\mathrm{Mg} /$ biochar and biochar were rich in organic functional groups, including $\mathrm{O}-\mathrm{H}, \mathrm{C}=\mathrm{O}, \mathrm{C}=\mathrm{C}$, and $\mathrm{C}-\mathrm{Cl}$.

Similarly, the yield analysis (Table 2) show that yields of biochar and $\mathrm{Mg} /$ biochar decreased when pyrolysis temperature increased from room temperature to $300{ }^{\circ} \mathrm{C}$. Furthermore, the weights of biochar and $\mathrm{Mg} /$ biochar decreased by $48.5 \%$ and $46.4 \%$, respectively. These weights were reduced further by $16.6 \%$ and $16.7 \%$ when the pyrolysis temperature increased from $300{ }^{\circ} \mathrm{C}$ to $450{ }^{\circ} \mathrm{C}$, respectively. The weights decreased by another $3.0 \%$ and $2.2 \%$ when the pyrolysis temperature increased from $450{ }^{\circ} \mathrm{C}$ to $600{ }^{\circ} \mathrm{C}$, respectively. The decreasing yield trend indicated the loss of chemical composition in the corn. Raw corn generally contained roughly $12.5 \%$ lignin, $40 \%$ cellulose, and $20 \%$ hemicelluloses [22]. 
However, these chemical compositions were destroyed and volatilized by the increased pyrolysis temperature [23]. Moreover, the yield of $\mathrm{Mg} / \mathrm{biochar}$ over than that of biochar by $2.0 \%$ to $2.8 \%$ suggested that this portion of the yield corresponded to magnesium content.

Table 2. Characteristic of corn, biochar, and $\mathrm{Mg} / \mathrm{biochar}$.

\begin{tabular}{cccccc}
\hline Sample & Yield $(\boldsymbol{\%})$ & $\mathbf{C}(\boldsymbol{\%})$ & $\mathbf{H}(\boldsymbol{\%})$ & $\mathbf{N}(\boldsymbol{\%})$ & BET-N $_{\mathbf{2}}$ Surface Area $\left(\mathbf{m}^{2} / \mathbf{g}\right)$ \\
\hline corn & -- & 35.46 & 6.327 & 0.72 & - \\
B300 & 51.5 & 48.82 & 5.642 & 0.70 & 388.193 \\
B450 & 34.9 & 65.96 & 3.670 & 0.76 & 425.477 \\
B600 & 31.9 & 70.64 & 2.544 & 0.73 & 494.929 \\
$\mathrm{Mg} / \mathrm{B} 300$ & 53.6 & 46.89 & 5.420 & 0.67 & 382.114 \\
$\mathrm{Mg} / \mathrm{B} 450$ & 36.9 & 62.33 & 3.470 & 0.72 & 421.492 \\
$\mathrm{Mg} / \mathrm{B} 600$ & 34.7 & 65.06 & 2.430 & 0.67 & 490.294 \\
\hline
\end{tabular}

The $\mathrm{CHN}$ element analysis (Table 2) shows an increase in pyrolysis temperature induces an increase in $\mathrm{C}$ content, and a decrease in $\mathrm{H}$ content, although $\mathrm{N}$ content remains unchanged. $\mathrm{C}$ content was mainly related to pyrolysis temperature; therefore, it increased with this temperature. The reduced $\mathrm{H}$ content indicates that the $\mathrm{H}-\mathrm{O}$ bond was broken and volatilized during the pyrolysis process and that additional aromatic rings were generated [24]. $\mathrm{N}$ content did not change significantly because the $\mathrm{N}$ functional groups could not form vaporized molecules. However, they generated new substances with complex structures [25]. The $\mathrm{C}, \mathrm{H}$, and $\mathrm{N}$ contents of $\mathrm{Mg} /$ biochar were lower than those of biochar because of the magnesium content in $\mathrm{Mg} / \mathrm{biochar}$.

The BET surface area analysis (Table 2) demonstrates that the BET surface areas of $\mathrm{Mg} / \mathrm{biochar}$ and biochar increased with pyrolysis temperature. It indicated the carbon structure of $\mathrm{Mg} / \mathrm{biochar}$ and biochar changed according to different pyrolysis processes. When the pyrogenation temperature was lower than $500{ }^{\circ} \mathrm{C}$, numerous mesopores were generated. When pyrogenation temperature was higher than $600{ }^{\circ} \mathrm{C}$, mesopore structures collapsed [26]. Furthermore, the surface area of $\mathrm{Mg} / \mathrm{biochar}$ was close to that of biochar at a constant pyrogenation temperature. Therefore, the embedded magnesium nanoparticles did not block the mesoporous structures.

The TEM analysis (Figure 1) shows that the number of mesoporous structures increased with the increase in pyrolysis temperature. In the process, the distribution of these structures was changed from order to disorder. Lots of magnesium nanoparticles were presence in $\mathrm{Mg} / \mathrm{biochar}$. The mesoporous structure was not obvious in B300 and $\mathrm{Mg} / \mathrm{B} 300$, thereby suggesting that the temperature did not reach the threshold at which mesoporous structures open. The mesoporous structures of B450 and Mg/B450 were clear and densely arranged. Portions of the mesoporous structures of B600 and $\mathrm{Mg} / \mathrm{B} 600$ collapsed and aggravated the chaotic distribution of mesopores.

The FTIR analysis (Figure 2) demonstrates that the character peaks of Mg/biochar are similar to those of biochar and that magnesium nanoparticles do not affect the structural formation of organic functional groups in $\mathrm{Mg} / \mathrm{biochar}$. The character peaks at $3200 \mathrm{~cm}^{-1}-3700 \mathrm{~cm}^{-1}, 1400 \mathrm{~cm}^{-1}-1690 \mathrm{~cm}^{-1}$, and $550 \mathrm{~cm}^{-1}-850 \mathrm{~cm}^{-1}$ represented the hydroxyl $(\mathrm{O}-\mathrm{H})$, double bonds $(\mathrm{C}=\mathrm{O}$ and $\mathrm{C}=\mathrm{C})$, and organic chloride $(\mathrm{C}-\mathrm{Cl})$. Thus, $\mathrm{Mg} /$ biochar and biochar are rich in organic functional groups, such as $\mathrm{O}-\mathrm{H}, \mathrm{C}=\mathrm{O}$, $\mathrm{C}=\mathrm{C}$, and $\mathrm{C}-\mathrm{Cl}$, which benefit adsorption [17]. 
The surface area, number and distribution of mesopores, and organic functional groups are important factors in physical adsorption [27]. An increase in pyrolysis temperature induces increases in surface area and in the number of mesopores. Furthermore, mesopore distribution becomes disordered and organic functional groups are produced. As a result, the $\mathrm{P}$ adsorption capabilities of $\mathrm{Mg} / \mathrm{biochar}$ and biochar are enhanced. With magnesium nanoparticles impregnated, $\mathrm{Mg} /$ biochar adsorption is driven by physical and chemical action, whereas biochar adsorption relies only on physical action.

Figure 1. TEM analysis of biochar and $\mathrm{Mg} / \mathrm{biochar}$.

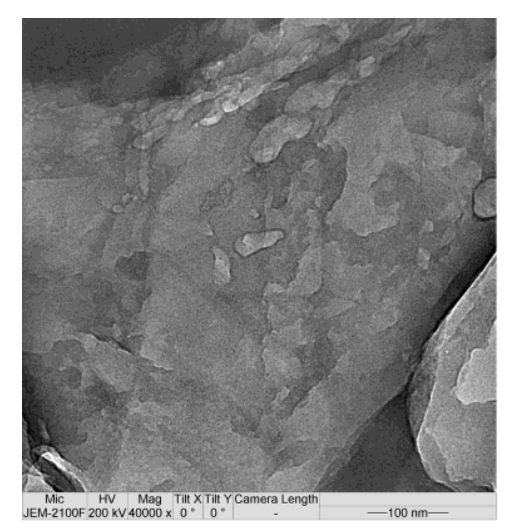

B300

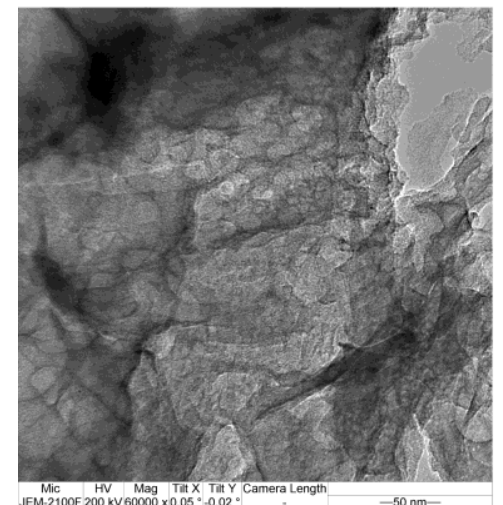

$\mathrm{B} 600$

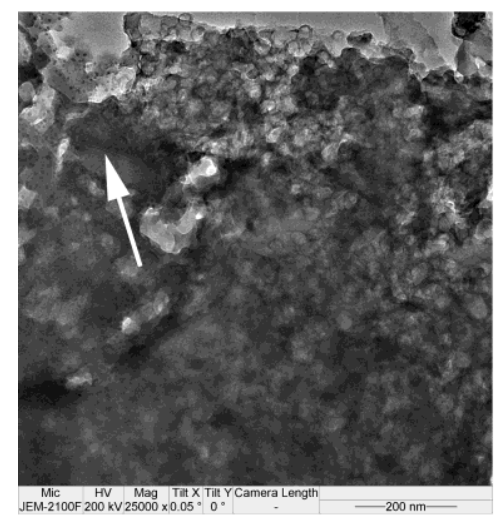

$\mathrm{Mg} / \mathrm{B} 450$

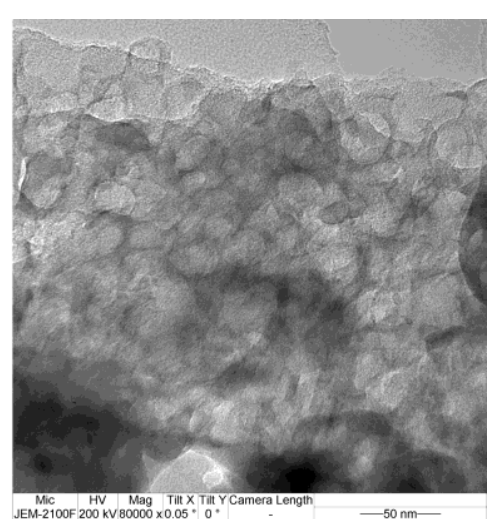

B450

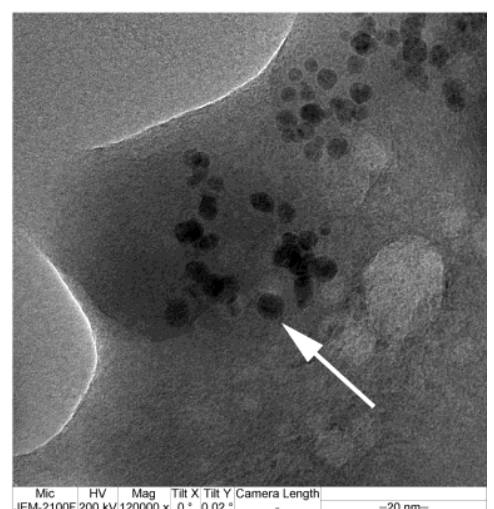

Mg/B300

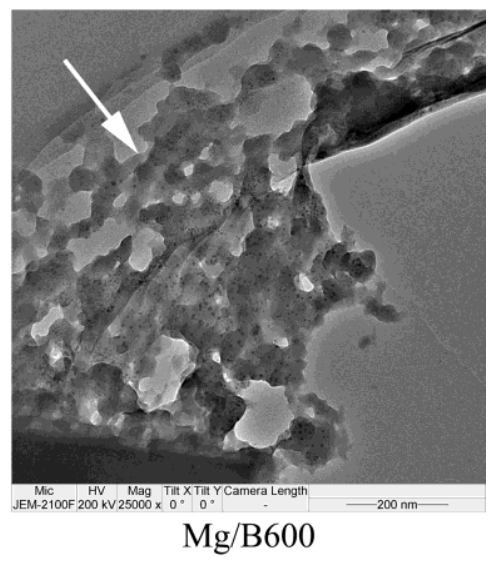


Figure 2. FTIR analysis of Mg/biochar and biochar.

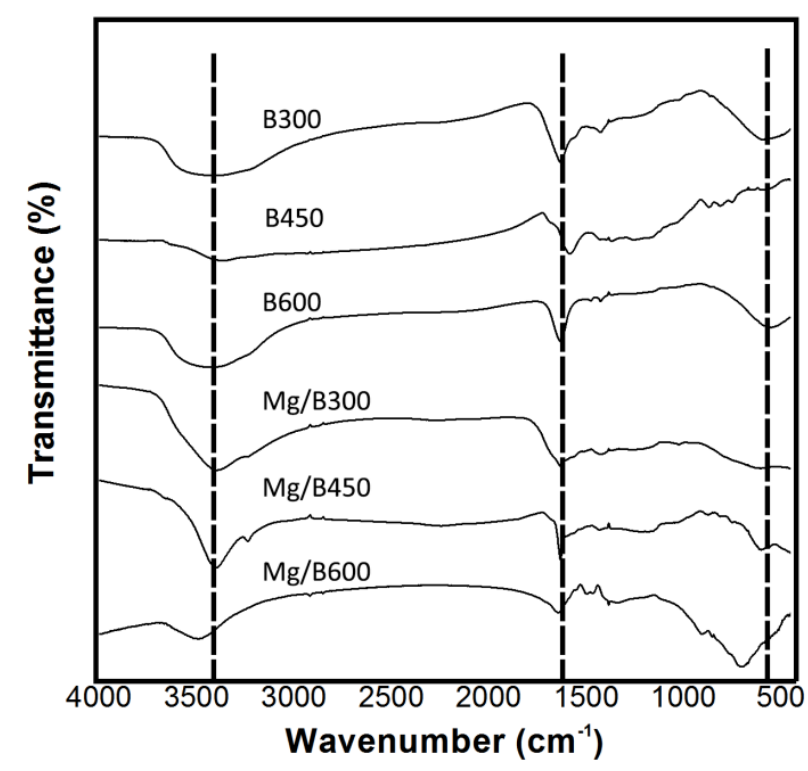

\subsection{P Adsorption Efficiency}

\subsubsection{Adsorption Kinetics}

The $\mathrm{P}$ adsorption kinetics of $\mathrm{Mg} / \mathrm{biochar}$ and biochar were fitted to three kinetic models (Figure 3). The results demonstrated that the $\mathrm{P}$ adsorption process of $\mathrm{Mg} /$ biochar was mainly controlled by chemical action, whereas that of biochar was mainly driven by physical action. Furthermore, embedded magnesium nanoparticles could accelerate $\mathrm{Mg} /$ biochar adsorption.

Figure 3. (a) $\mathrm{P}$ adsorption kinetics of $\mathrm{Mg} / \mathrm{B} 300$ and $\mathrm{B} 300$; (b) $\mathrm{P}$ adsorption kinetics of $\mathrm{Mg} / \mathrm{B} 450$ and B450; (c) $\mathrm{P}$ adsorption kinetics of $\mathrm{Mg} / \mathrm{B} 600$ and $\mathrm{B} 600$.

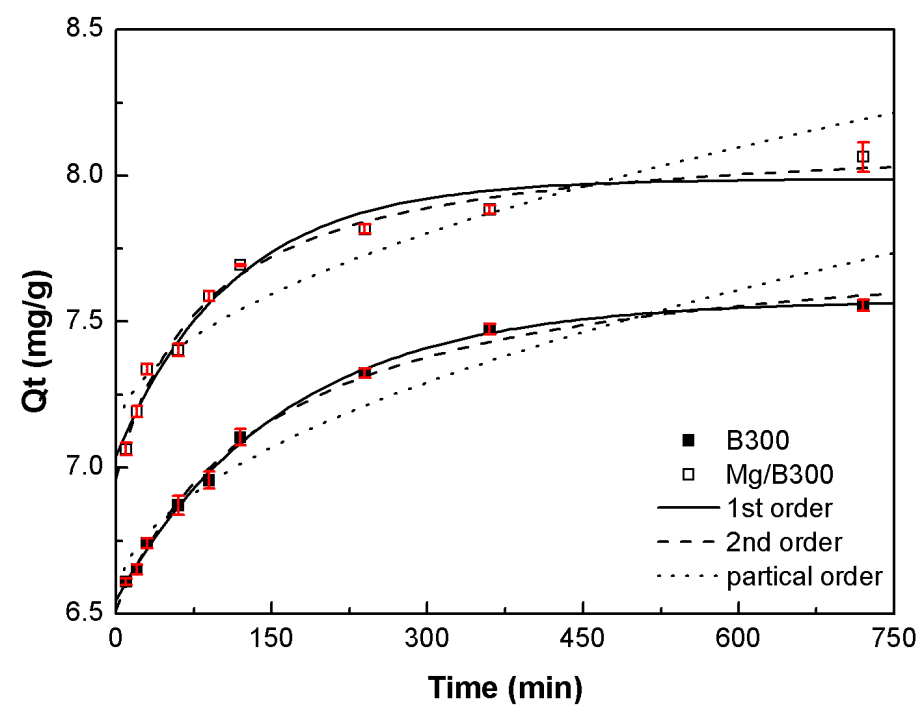

(a) 
Figure 3. Cont.

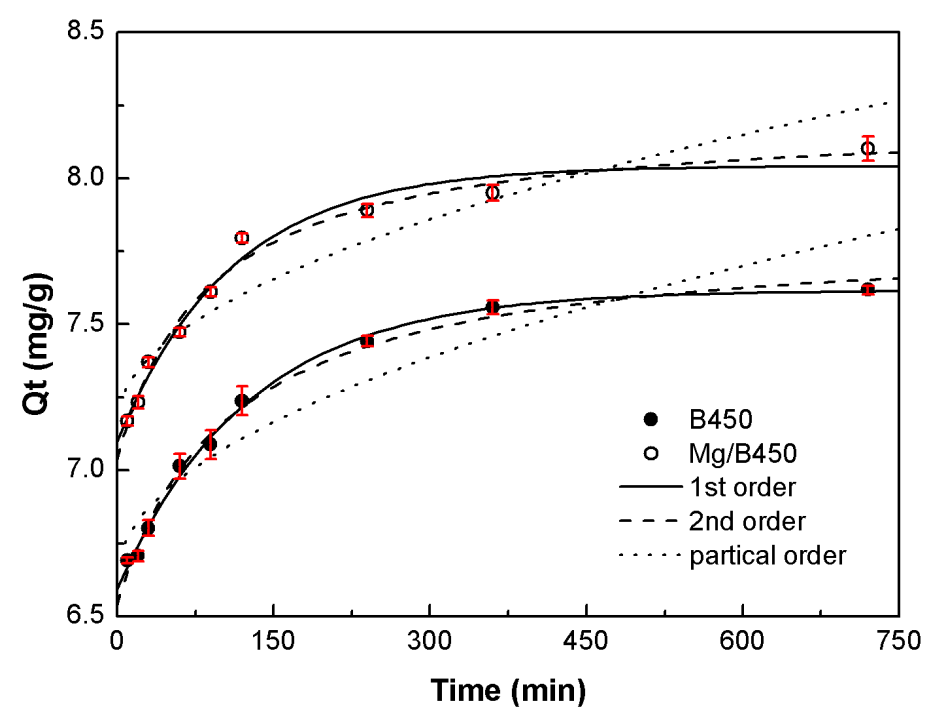

(b)

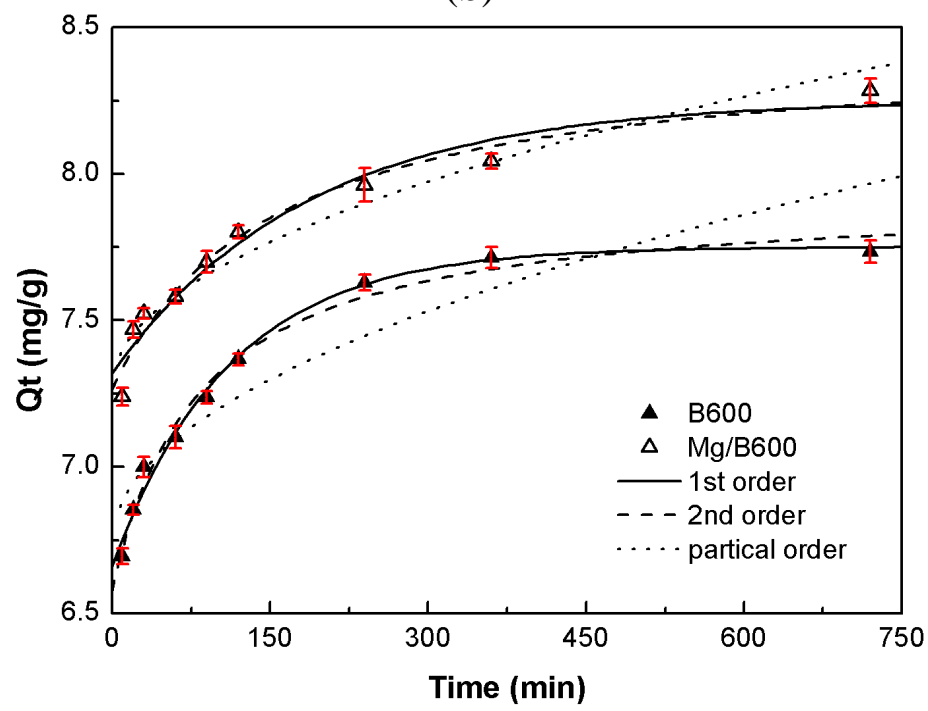

(c)

The linear equation of pseudo first-order can be expressed as follows:

$$
\ln \left(Q_{e}-Q_{t}\right)=\ln Q_{e}-k_{1} t
$$

The linear equation of pseudo second-order can be expressed as follows:

$$
\frac{t}{Q_{t}}=\frac{1}{k_{2} Q_{e}{ }^{2}}+\frac{t}{Q_{e}}
$$

The particle diffusion equation can be expressed as follows:

$$
Q_{t}=k_{i d} t^{\frac{1}{2}}+C
$$

where $Q_{e}\left(\mathrm{mg} \cdot \mathrm{g}^{-1}\right)$ is the adsorbed amount of $\mathrm{P}$ at equilibrium, $Q_{t}\left(\mathrm{mg} \cdot \mathrm{g}^{-1}\right)$ is the adsorbed amount of $\mathrm{P}$ at time $t, k_{1}\left(\mathrm{~h}^{-1}\right), k_{2}\left(\mathrm{~g} \cdot \mathrm{mg}^{-1} \cdot \mathrm{h}^{-1}\right)$, and $k_{i d}\left(\mathrm{~g} \cdot \mathrm{mg}^{-1} \cdot \mathrm{h}^{-1}\right)$ are reaction rate constants, and $C$ is a constant related to boundary layer thickness. Table 3 shows the parameters of the three kinetic models. 
Table 3. Phosphorus (P) adsorption kinetics parameter of $\mathrm{Mg} /$ biochar and biochar.

\begin{tabular}{|c|c|c|c|c|}
\hline Sample & Parameters & 1st-Order & 2nd-Order & Piratical-Order \\
\hline \multirow{3}{*}{ B300 } & Parameter 1 & $k_{1}=(6.16 \pm 0.36) \times 10^{-3}$ & $k_{2}=(0.850 \pm 0.122) \times 10^{-3}$ & $K_{i d}=(44.1 \pm 4.5) \times 10^{-3}$ \\
\hline & Parameter 2 & $Q_{e}=7.57 \pm 0.02$ & $Q_{e}=7.81 \pm 0.06$ & $C=6.53 \pm 0.06$ \\
\hline & $R^{2}$ & 0.997 & 0.992 & 0.923 \\
\hline \multirow{3}{*}{ B450 } & Parameter 1 & $k_{1}=(7.88 \pm 0.61) \times 10^{-3}$ & $k_{2}=(1.20 \pm 0.20) \times 10^{-3}$ & $K_{i d}=(43.7 \pm 5.7) \times 10^{-3}$ \\
\hline & Parameter 2 & $Q_{e}=7.62 \pm 0.02$ & $Q_{e}=7.82 \pm 0.05$ & $C=6.63 \pm 0.08$ \\
\hline & $R^{2}$ & 0.994 & 0.989 & 0.880 \\
\hline \multirow{3}{*}{ B600 } & Parameter 1 & $k_{1}=(9.06 \pm 1.04) \times 10^{-3}$ & $k_{2}=(1.55 \pm 0.33) \times 10^{-3}$ & $K_{i d}=(45.5 \pm 6.9) \times 10^{-3}$ \\
\hline & Parameter 2 & $Q_{e}=7.74 \pm 0.03$ & $Q_{e}=7.92 \pm 0.06$ & $C=6.74 \pm 0.09$ \\
\hline & $R^{2}$ & 0.987 & 0.982 & 0.840 \\
\hline \multirow{3}{*}{$\mathrm{Mg} / \mathrm{B} 300$} & Parameter 1 & $k_{1}=(8.90 \pm 1.73) \times 10^{-3}$ & $k_{2}=(1.45 \pm 0.32) \times 10^{-3}$ & $K_{i d}=(41.0 \pm 5.2) \times 10^{-3}$ \\
\hline & Parameter 2 & $Q_{e}=7.99 \pm 0.05$ & $Q_{e}=8.15 \pm 0.06$ & $C=7.09 \pm 0.07$ \\
\hline & $R^{2}$ & 0.962 & 0.981 & 0.884 \\
\hline \multirow{3}{*}{$\mathrm{Mg} / \mathrm{B} 450$} & Parameter 1 & $k_{1}=(9.13 \pm 1.47) \times 10^{-3}$ & $k_{2}=(1.40 \pm 0.30) \times 10^{-3}$ & $K_{i d}=(40.4 \pm 5.5) \times 10^{-3}$ \\
\hline & Parameter 2 & $Q_{e}=8.04 \pm 0.04$ & $Q_{e}=8.21 \pm 0.06$ & $C=7.16 \pm 0.07$ \\
\hline & $R^{2}$ & 0.974 & 0.983 & 0.871 \\
\hline \multirow{3}{*}{$\mathrm{Mg} / \mathrm{B} 600$} & Parameter 1 & $k_{1}=(5.39 \pm 1.42) \times 10^{-3}$ & $k_{2}=(0.778 \pm 0.251) \times 10^{-3}$ & $K_{i d}=(40.6 \pm 3.7) \times 10^{-3}$ \\
\hline & Parameter 2 & $Q_{e}=8.25 \pm 0.09$ & $Q_{e}=8.44 \pm 0.11$ & $C=7.27 \pm 0.05$ \\
\hline & $R^{2}$ & 0.944 & 0.962 & 0.938 \\
\hline
\end{tabular}

The $\mathrm{P}$ adsorption process of $\mathrm{Mg} / \mathrm{bioch}$ ar conformed to the pseudo second-order kinetic model and can adsorb $90 \%$ of the equilibrium amount of $\mathrm{P}$ within $30 \mathrm{~min}$, thereby confirming that the $\mathrm{P}$ adsorption process was mainly controlled by chemical action [13]. The surface charge of biochar is generally lower, which limits its effect on P adsorption [23]. Magnesium nanoparticles can increase this surface charge, thus improving and accelerating $\mathrm{P}$ adsorption. The chemical electrostatic reaction of magnesium particles with $\mathrm{P}$ may thus be crucial to rate control. The value of $k_{2}$ represents the power of $\mathrm{P}$ adsorption, and it decreases with an increase in pyrolysis temperature. Therefore, the $\mathrm{P}$ adsorption rate of $\mathrm{Mg} /$ biochar decelerates with the increase in pyrolysis temperature while the effect of physical adsorption increases. In other words, additional $\mathrm{P}$ adsorption sites are provided to reduce the effect of chemical adsorption, comparatively.

The $\mathrm{P}$ adsorption process of biochar conformed to the pseudo first-order kinetic model and can adsorb up to $90 \%$ of the equilibrium amount of $\mathrm{P}$ after $30 \mathrm{~min}$, thereby confirming that the $\mathrm{P}$ adsorption process was mainly driven by physical action [13]. The hydrogen bonding interaction, supply more adsorption sites, is the main reason of physical action for $\mathrm{P}$ adsorption by biochar. The rate constant $k_{1}$ increased with the increase in pyrolysis temperature. Thus, physical adsorption was enhanced, the number of $\mathrm{P}$ adsorption sites increased, and the $\mathrm{P}$ adsorption rate of biochar accelerated.

The particle diffusion fitting models of $\mathrm{Mg} /$ biochar and biochar did not pass through the origin point, thus suggesting that the $\mathrm{P}$ adsorption process of $\mathrm{Mg} / \mathrm{biochar}$ and biochar were also influenced by the particle internal diffusion [28]. 


\subsubsection{Adsorption Isotherms}

The $\mathrm{P}$ adsorption isotherms of $\mathrm{Mg} / \mathrm{bioch}$ ar and biochar were fitted to three adsorption isothermal models (Figure 4). Among these models, the Langmuir-Freundlich model was the one that best fit the P adsorption of both $\mathrm{Mg} / \mathrm{biochar}$ and biochar. The maximum amounts of adsorbed $\mathrm{P}$ were $239 \mathrm{mg} / \mathrm{g}$ and $225 \mathrm{mg} / \mathrm{g}$ for $\mathrm{Mg} / \mathrm{biochar}$ and bicohar, respectively. The maximum $\mathrm{P}$ adsorption amount of $\mathrm{Mg} / \mathrm{biochar}$ was higher than that of biochar.

The Freundlich isothermal equation for adsorption describes non-ideal adsorption on a non-uniform surface and is expressed as follows:

$$
Q_{e}=K_{F} C_{e}^{1 / n}
$$

The Langmuir isothermal equation for adsorption describes the monolayer adsorption on a uniform surface and is expressed as follows:

$$
Q_{e}=\frac{Q_{m} K_{L} C_{e}}{1+K_{L} C_{e}}
$$

The Langmuir-Freundlich isothermal equation for adsorption integrates the empirical isothermal equations of Freundlich and Langmuir, which can be expressed as follows:

$$
Q_{e}=\frac{Q_{m} K C_{e}^{1 / n}}{1+K C_{e}^{1 / n}}
$$

where $K_{F}\left[(\mathrm{~L} / \mathrm{g})^{\mathrm{n}}\right], K_{L}(\mathrm{~L} / \mathrm{mg})$, and $K(\mathrm{~L} / \mathrm{mg})$ are the constant of Freundlich, Langmuir, and Langmuir-Freundlich adsorption isothermal equation, respectively. A parameter relevant to the reaction strength between adsorbed molecules and adsorbent surface is $1 / n . Q_{m}(\mathrm{mg} / \mathrm{g})$ denotes monolayer adsorption capacity.

Figure 4. (a) $\mathrm{P}$ adsorption isotherm of $\mathrm{Mg} / \mathrm{B} 300$ and $\mathrm{B} 300$; (b) $\mathrm{P}$ adsorption isotherm of $\mathrm{Mg} / \mathrm{B} 450$ and $\mathrm{B} 450$; (c) $\mathrm{P}$ adsorption isotherm of $\mathrm{Mg} / \mathrm{B} 600$ and $\mathrm{B} 600$.

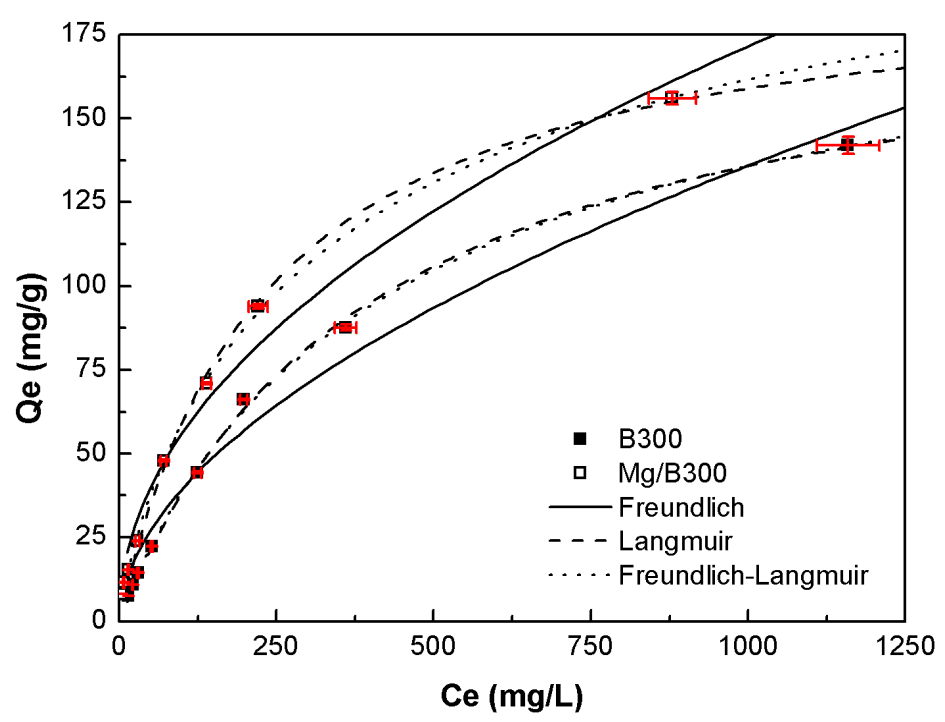

(a) 
Figure 4. Cont.

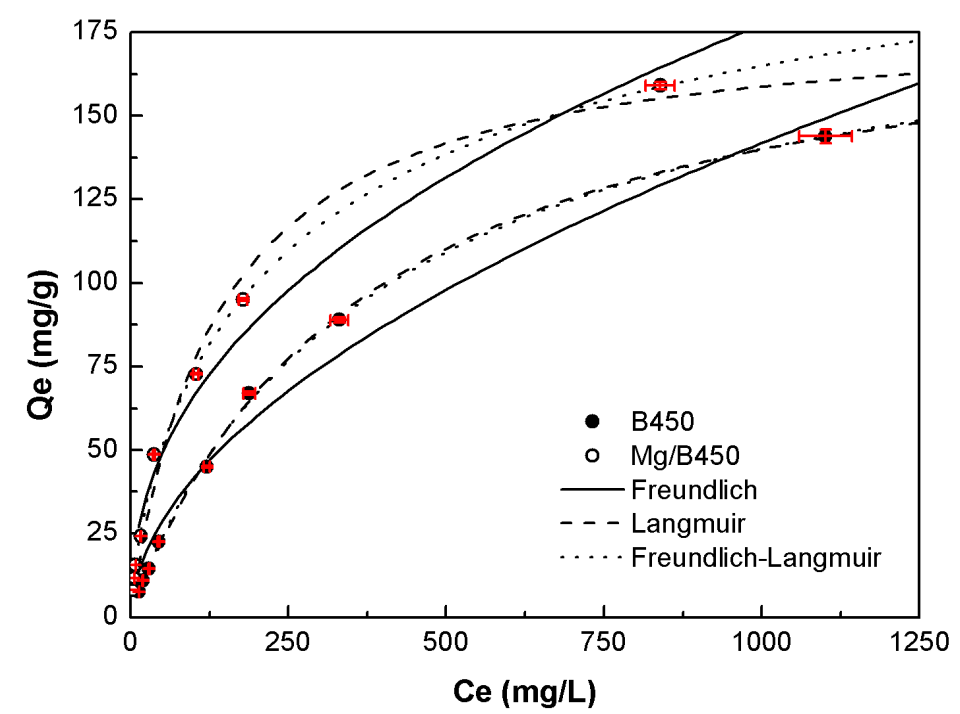

(b)

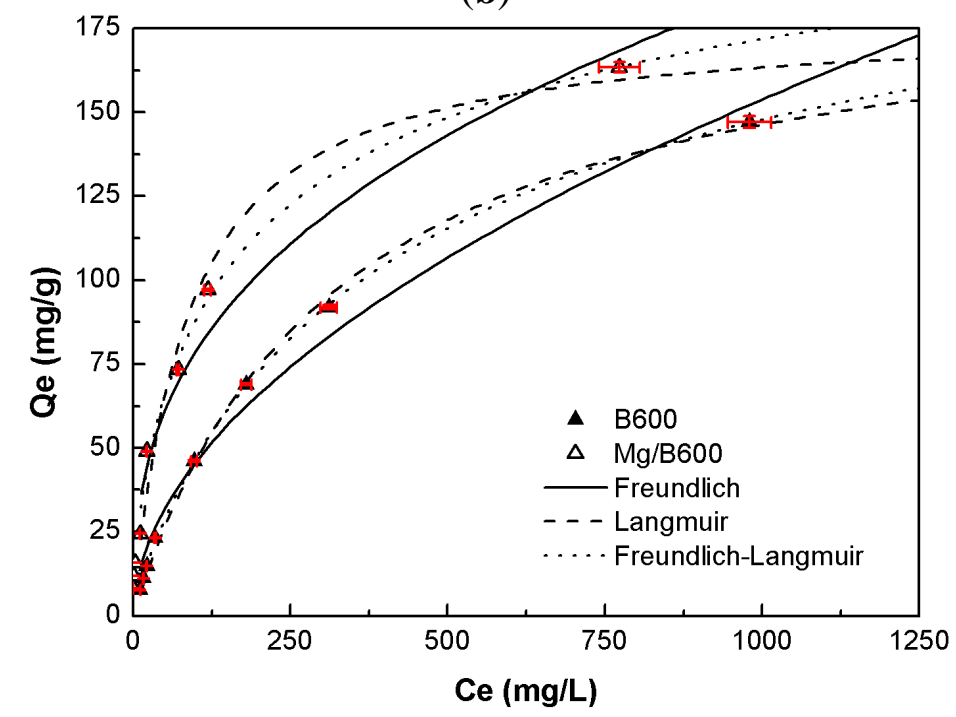

(c)

Table 4 indicates that the three models fit the $\mathrm{P}$ adsorption isotherms of $\mathrm{Mg} / \mathrm{biochar}$ and biochar well $\left(R^{2}>0.97\right)$. Among the three models, however, the Langmuir-Freundlich model was the best fit. This finding suggests that the adsorption capabilities of $\mathrm{P}$ from swine wastewater by $\mathrm{Mg} / \mathrm{biochar}$ and biochar were both controlled by multiple processes. The results obtained in the current study were also similar to those of previous research [11]. The value of $1 / n$ represents the heterogeneity of the site energies and has been divided to five levels [29]. When the value of $1 / n$ is between 1 and 0.5 , the adsorption is categorized as pseudo-linear level. The smaller the value of $1 / n$ is, the more favorable the adsorption is. Moreover, the $1 / n$ of $\mathrm{Mg} / \mathrm{biochar}$ and biochar decreased as the synthesis temperature increased. Thus, the adsorption capabilities of both $\mathrm{Mg} /$ biochar and biochar tended to be favorable adsorption with increased synthesis temperature. The $1 / n$ of $\mathrm{Mg} /$ biochar was greater than that of biochar at the same synthesis temperature. Therefore, $\mathrm{Mg}$ /biochar can absorb $\mathrm{P}$ more easily than biochar, even at a low concentration level [29]. The $K$ values of $\mathrm{Mg} / \mathrm{bioch}$ ar and biochar increased with synthesis temperature increased, that suggested that the adsorption capacity increased [30]. The $K$ value of $\mathrm{Mg} / \mathrm{bioch}$ ar was higher than that of 
biochar at the same synthesis temperature, which indicated the adsorption capacity of $\mathrm{Mg} / \mathrm{biochar}$ was larger than that of biochar at the same synthesis temperature. The maximum $\mathrm{P}$ adsorption amounts were $232 \mathrm{mg} / \mathrm{g}, 233 \mathrm{mg} / \mathrm{g}$, and $239 \mathrm{mg} / \mathrm{g}$ for $\mathrm{Mg} / \mathrm{B} 300, \mathrm{Mg} / \mathrm{B} 450$, and $\mathrm{Mg} / \mathrm{B} 600$, respectively, as fitted by the Langmiur-Freundlich model. The maximum P adsorption amounts were $200 \mathrm{mg} / \mathrm{g}, 201 \mathrm{mg} / \mathrm{g}$, and $225 \mathrm{mg} / \mathrm{g}$ for B300, B450, and B600, respectively, as fitted by the Langmiur-Freundlich model. The maximum amount of $\mathrm{P}$ adsorbed by $\mathrm{Mg} /$ biochar was higher than that adsorbed by biochar, thereby demonstrating that $\mathrm{Mg} / \mathrm{biochar}$ can enhance the amount of $\mathrm{P}$ adsorbed from swine wastewater.

Table 4. $\mathrm{P}$ adsorption isotherm parameter of $\mathrm{Mg} / \mathrm{biochar}$ and biochar.

\begin{tabular}{cccccccc}
\hline Models & & $\mathbf{B 3 0 0}$ & $\mathbf{B 4 5 0}$ & $\mathbf{B 6 0 0}$ & $\mathbf{M g} / \mathbf{B 3 0 0}$ & $\mathbf{M g} / \mathbf{B 4 5 0}$ & $\mathbf{M g} / \mathbf{B 6 0 0}$ \\
\hline \multirow{2}{*}{ Freundlich } & $K_{F}$ & $3.29 \pm 0.87$ & $3.55 \pm 0.94$ & $4.05 \pm 0.90$ & $5.95 \pm 1.22$ & $9.12 \pm 1.76$ & $14.3 \pm 2.4$ \\
& $n$ & $0.539 \pm 0.041$ & $0.534 \pm 0.042$ & $0.526 \pm 0.035$ & $0.487 \pm 0.033$ & $0.429 \pm 0.032$ & $0.371 \pm 0.028$ \\
& $\mathrm{R}^{2}$ & 0.974 & 0.973 & 0.984 & 0.980 & 0.977 & 0.973 \\
\hline \multirow{6}{*}{ Langmuir } & $K_{L}\left(\times 10^{-3}\right)$ & $2.53 \pm 0.13$ & $2.72 \pm 0.14$ & $3.15 \pm 0.22$ & $4.34 \pm 0.37$ & $7.35 \pm 1.17$ & $11.7 \pm 2.3$ \\
& $Q_{m}$ & $190 \pm 4$ & $191 \pm 4$ & $193 \pm 6$ & $196 \pm 7$ & $180 \pm 11$ & $177 \pm 12$ \\
& $\mathrm{R}^{2}$ & 0.999 & 0.999 & 0.997 & 0.995 & 0.984 & 0.973 \\
\hline \multirow{6}{*}{ Langmuir-Freundlich } & $K\left(\times 10^{-3}\right)$ & $3.07 \pm 0.50$ & $3.30 \pm 0.54$ & $5.03 \pm 0.32$ & $7.73 \pm 0.88$ & $16.6 \pm 2.1$ & $31.0 \pm 5.0$ \\
& $Q_{m}$ & $200 \pm 11$ & $201 \pm 11$ & $225 \pm 7$ & $232 \pm 14$ & $233 \pm 21$ & $239 \pm 35$ \\
& $n$ & $0.947 \pm 0.044$ & $0.947 \pm 0.045$ & $0.860 \pm 0.020$ & $0.823 \pm 0.038$ & $0.721 \pm 0.051$ & $0.638 \pm 0.076$ \\
& $\mathrm{R}^{2}$ & 0.999 & 0.999 & 1.000 & 0.999 & 0.997 & 0.992 \\
\hline
\end{tabular}

\subsubsection{Thermodynamic Calculation}

The $\mathrm{P}$ adsorption capabilities of $\mathrm{Mg} /$ biochar and biochar were thermodynamically calculated at $288 \mathrm{~K}, 303 \mathrm{~K}$, and $318 \mathrm{~K}$. The Langmuir-Freundlich model was used to compute the differential enthalpy of adsorption $(\Delta H)$, adsorption free energy $(\Delta G)$, and adsorption entropy $(\Delta S)$. The analysis indicated that the $\mathrm{P}$ adsorpiton processes of $\mathrm{Mg} / \mathrm{biochar}$ and biochar were endothermic, spontaneous, and disorder increase process.

The adsorption enthalpy of the adsorbent is closely related to the adsorption amount. When the adsorption amount is initialized at one value, the corresponding adsorption enthalpy is known as the differential enthalpy of adsorption. Its calculation formula can be expressed as follows:

$$
\ln \left(\frac{1}{C_{e}}\right)=\ln K^{\prime}-\frac{\Delta H}{R T}
$$

where $R\left(8.314 \mathrm{~J} \cdot \mathrm{mol}^{-1} \cdot \mathrm{K}^{-1}\right)$ is the ideal gas constant; $T(\mathrm{~K})$ is thermodynamic temperature; and $K^{\prime}$ represents a constant. Adsorption free energy can be computed using Gibbs equation, which can be expressed as follows:

$$
\Delta G=-R T \int_{0}^{x}\left(\frac{q^{\prime}}{x}\right) d x
$$

where $x$ is the mole fraction of the solute in the solution; and $q^{\prime}(\mathrm{mmol} / \mathrm{g})$ is the adsorption amount of the adsorbent. When $\Delta G$ is irrelevant to $q^{\prime}$, the formula is altered as follows:

$$
\Delta G=-n R T
$$


Adsorption entropy can be calculated using $\Delta H$ and $\Delta G$ with the formula below:

$$
\Delta S=\frac{(\Delta H-\Delta G)}{T}
$$

The thermodynamic parameters were given in the Table 5. The $\Delta H$ of both $\mathrm{Mg} / \mathrm{biochar}$ and biochar were positive values, thus, indicating that their $\mathrm{P}$ adsorptions were endothermic reaction processes. The $\Delta G$ of both $\mathrm{Mg} / \mathrm{biochar}$ and biochar were less than 0 , thereby suggesting that $\mathrm{P}$ was spontaneous and moved from the solution to the surface of either the $\mathrm{Mg} /$ biochar or the biochar. In addition, the $\Delta G$ values of $\mathrm{Mg} / \mathrm{biochar}$ and biochar decreased as solution temperature increased. This result illustrated that both $\mathrm{Mg} /$ biochar and biochar could adsorb P efficiency at a high solution temperature [31]. The $\Delta S$ of $\mathrm{Mg} / \mathrm{biochar}$ and biochar were positive, thus, indicating that the solid-liquid interface was increasingly disordered during the $\mathrm{P}$ adsorption processes. Adsorption and desorption generally occurs simultaneously, and the $\Delta S$ value increase or decrease has been depend on the effect of desorption process and the adsorption process. $\Delta S$ value decreased with the increased in solution temperature during $\mathrm{P}$ adsorption by $\mathrm{Mg} /$ biochar and biochar, thus, illustrating that the $\Delta S$ decreased of adsorption process became much more powerful than the $\Delta S$ increased of desorption process at a higher solution temperature. Previous studies obtained similar results during $\mathrm{P}$ adsorption on $\mathrm{ZnCl}_{2}$ activated coir pith carbon [32] and $\mathrm{Mg}-\mathrm{Al}$ layered double hydroxide [33].

Table 5. Phosphorus (P) adsorption thermodynamics calculation of $\mathrm{Mg} /$ biochar and biochar.

\begin{tabular}{ccccc}
\hline Sample & $\boldsymbol{T}$ & $\Delta \boldsymbol{H}$ & $\Delta \boldsymbol{G}$ & $\Delta \boldsymbol{S}$ \\
\hline & 288 & & -2.26 & 45.4 \\
B300 & 303 & 10.8 & -2.39 & 43.6 \\
& 318 & & -2.43 & 41.6 \\
\hline & 288 & & -2.30 & 43.7 \\
B450 & 303 & 10.3 & -2.39 & 41.8 \\
& 318 & & -2.48 & 40.1 \\
\hline & 288 & & -1.95 & 41.0 \\
B600 & 303 & 9.87 & -2.17 & 39.7 \\
& 318 & & -2.18 & 37.9 \\
\hline & 288 & & -1.82 & 43.4 \\
Mg/B300 & 303 & 10.7 & -2.07 & 42.1 \\
& 318 & & -2.15 & 40.3 \\
\hline & 288 & & -1.61 & 52.3 \\
Mg/B450 & 303 & 13.5 & -1.82 & 50.4 \\
& 318 & & -1.92 & 48.3 \\
\hline & 288 & & -1.53 & 75.7 \\
Mg/B600 & 303 & 20.3 & -1.61 & 72.2 \\
& 318 & & -1.72 & 69.2 \\
\hline
\end{tabular}




\subsection{P Adsorption Selectivity}

\subsubsection{Influence of $\mathrm{pH}$}

The $\mathrm{pH}$ influence analysis (Figure 5) demonstrated that the resistance of $\mathrm{Mg} / \mathrm{biochar}$ to $\mathrm{pH}$ was stronger than that of biochar because of the embedded $\mathrm{Mg}$ nanoparticles. As $\mathrm{pH}$ increased from 6 to 10, the amount of $\mathrm{P}$ adsorbed by $\mathrm{Mg} /$ biochar increased and reached its maximum amount at $\mathrm{pH} 9$ before decreasing, whereas the amount of $\mathrm{P}$ adsorbed by biochar was decreased slightly.

Figure 5. The $\mathrm{pH}$ influence on $\mathrm{P}$ adsorption of $\mathrm{Mg} / \mathrm{bioch} a r$ and biochar.

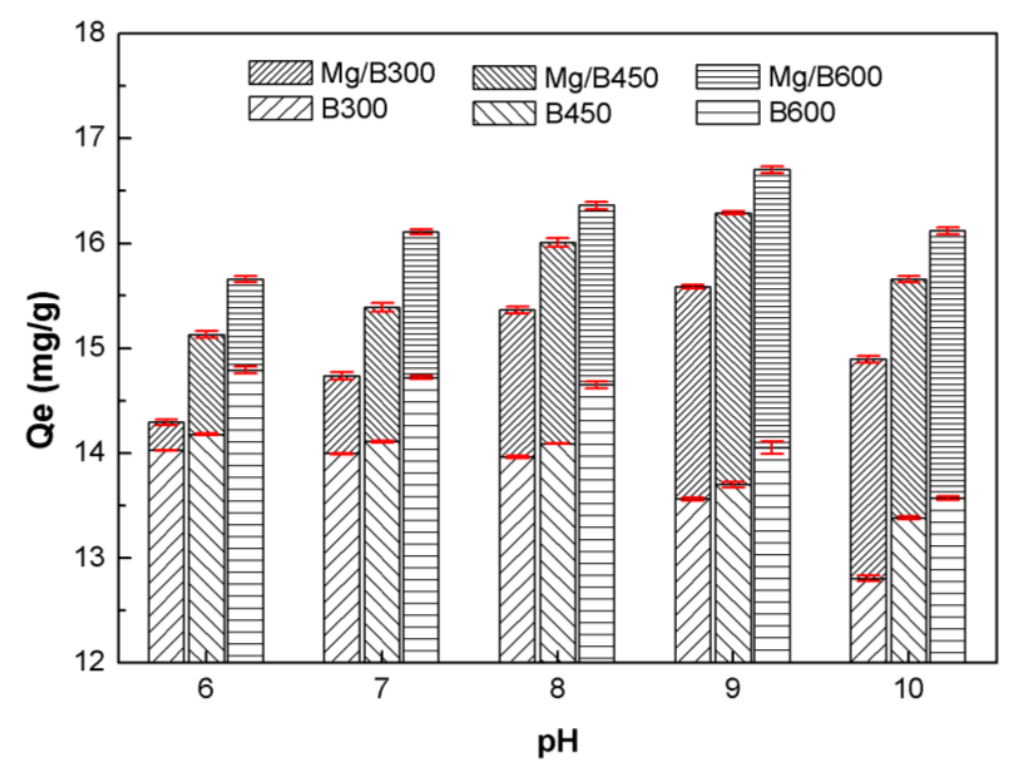

$\mathrm{P}$ is ternary acid whose ionization constants are $2.15,7.20$, and 12.33 . When the $\mathrm{pH}$ is between 6 and 7.21, $\mathrm{H}_{2} \mathrm{PO}_{4}{ }^{-}$is the superior in solution form. The adsorption capability of biochar relied only on physical action and was related to the quantity and distribution of mesoporous structures, surface area, and organic functional groups. However, the adsorption capability of $\mathrm{Mg} / \mathrm{biochar}$ depended on a combination of physical and chemical adsorption. The chemical action of the embedded magnesium nanoparticles on $\mathrm{P}$ increased as $\mathrm{pH}$ increased. However, an acid solution environment $(\mathrm{pH}<6)$ is disadvantageous for an $\mathrm{Mg}-\mathrm{P}$ reaction. When $\mathrm{pH}$ is between 7.21 and $9, \mathrm{HPO}_{4}{ }^{2-}$ is the superior in solution form. The adsorption ability of $\mathrm{Mg} / \mathrm{biochar}$ increased significantly as chemical action increased. However, the adsorption capability of biochar may decline further when additional adsorption sites are consumed as a result of polynuclear interactions [13]. Similar results were obtained with carbon-based adsorbents in studies of $\mathrm{pH}$ effect on $\mathrm{P}$ recovery [34]. Nonetheless, $\mathrm{OH}^{-}$competes with $\mathrm{PO}_{4}{ }^{3-}$ for the consumption of adsorption sites as $\mathrm{pH}$ increases from 9 to 10 . As a result, the $\mathrm{P}$ adsorption amounts of $\mathrm{Mg} / \mathrm{biochar}$ and biochar decreased further.

In conclusion, $\mathrm{Mg}$ /biochar shows affinity toward to $\mathrm{HPO}_{4}{ }^{2-}$, whereas biochar shows affinity toward $\mathrm{H}_{2} \mathrm{PO}_{4}{ }^{-}$. The $\mathrm{P}$ adsorption properties of $\mathrm{Mg}$ /biochar are altered by the $\mathrm{MgO}$ nanoparticles. The optimal $\mathrm{pH}$ range of $\mathrm{Mg} /$ biochar for the selective adsorption of $\mathrm{P}$ is close to the $\mathrm{pH}$ range of swine wastewater, thus indicating that $\mathrm{P}$ is effectively adsorbed by $\mathrm{Mg} / \mathrm{bioch}$ ar under the typical $\mathrm{pH}$ level of swine wastewater. 


\subsubsection{Influence of Coexisting Ions}

The influence of coexisting ions on $\mathrm{P}$ adsorption is an important indicator of the selective $\mathrm{P}$ adsorption by $\mathrm{Mg} / \mathrm{biochar}$, which is stronger than that of biochar when coexisting ions are present.

Figure 6 shows that the amounts of $\mathrm{P}$ adsorbed by $\mathrm{Mg} /$ biochar and biochar were higher in synthetic $\mathrm{P}$ wastewater than that in swine wastewater. The presence of coexisting ions in swine wastewater can, thus, reduce the selective adsorption of $\mathrm{P}$. The amounts of $\mathrm{P}$ adsorbed by $\mathrm{Mg} / \mathrm{B} 300, \mathrm{Mg} / \mathrm{B} 450$, and $\mathrm{Mg} / \mathrm{B} 600$ were lower in swine wastewater than in synthetic $\mathrm{P}$ wastewater by $6.6 \%, 4.8 \%$, and $4.2 \%$, respectively. The amounts of $\mathrm{P}$ adsorbed by B300, B450, and B600 were lower in swine wastewater than in synthetic $\mathrm{P}$ wastewater by $14.8 \%, 12.1 \%$, and $10.7 \%$, respectively.

Figure 6. Coexisting ion influence on $\mathrm{P}$ adsorption of $\mathrm{Mg} /$ biochar and biochar.

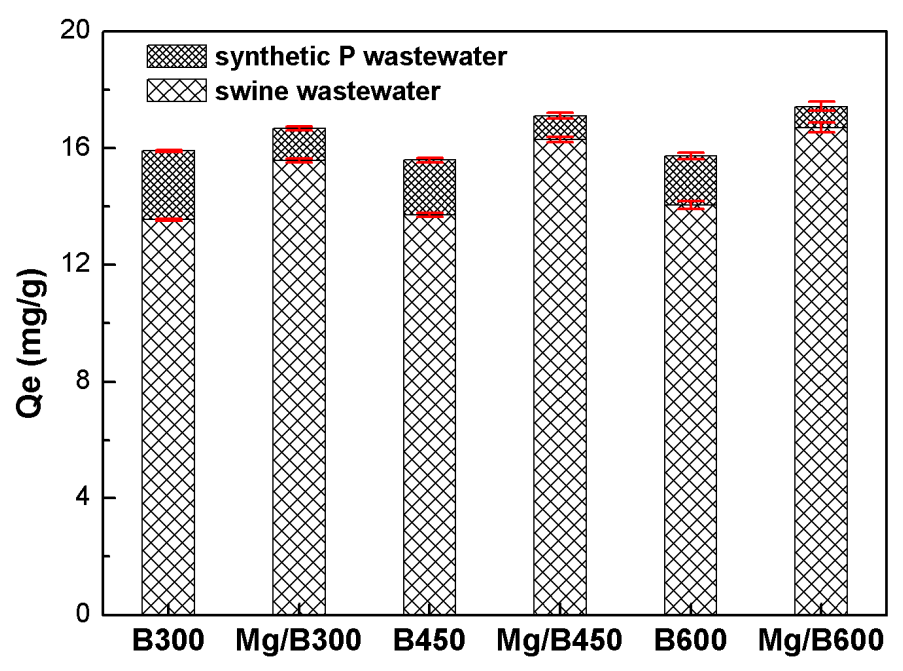

The negative interaction effects for $\mathrm{P}$ adsorption in swine wastewater may have a twofold origin. The first is the competitive effect of coexisting anions, including $\mathrm{Cl}^{-}, \mathrm{NO}_{3}{ }^{-}$, and so on. Single coexisting ions, such as $\mathrm{NO}_{3}{ }^{-}(0.01 \mathrm{M})$ and $\mathrm{HCO}_{3}{ }^{-}(0.01 \mathrm{M})$, could reduce the $\mathrm{P}$ removal ratio through biochar adsorption by $11.7 \%$ and $41.4 \%$, respectively $[13,21]$. The mixture of competing compounds can also limit the amount of $\mathrm{P}$ adsorbed by biochar by approximately 60\% [21]. The second is the co-precipitation effect of coexisting ions on the surface of $\mathrm{Mg} / \mathrm{biochar}$ and biochar, such as struvite, $\mathrm{CaHPO}_{4}, \mathrm{MgHCO}_{3}$, and so on, which occupy adsorption sites and block the mesopores. The dominant factor in the adsorption process should be identified in future studies. Nonetheless, the results obtained in the present study were better than other results [13,21]. It indicated that the chemical action of the magnesium nanoparticles in $\mathrm{Mg} /$ biochar could enhance the selective adsorption of $\mathrm{P}$ and limit the negative interaction effects of the coexisting ions in swine wastewater. Liu et al. [35] applied cation-loaded material, hydroxyl-iron-lanthanum doped activated carbon fiber, to adsorb $\mathrm{P}$ and hindered the negative effects on $\mathrm{P}$ adsorption. These results were close to those of the present studies.

Moreover, the influence of coexisting ions on $\mathrm{P}$ adsorption decreased with the increase in the pyrogenation temperatures of $\mathrm{Mg} /$ biochar and biochar. As a result, physical action was enhanced and resistance to the influence of coexisting ions was strengthened. 


\subsection{P Available Characterization}

Reuse $\mathrm{P}$ from postsorption $\mathrm{Mg} /$ biochar and postsorption biochar as soil nutrient is an effective method for P recycling, because it can enhance soil fertility for plant growth. Therefore, the P release character was performed to determine the available $\mathrm{P}$ obtained from postsorption $\mathrm{Mg} / \mathrm{biochar}$ and postsorption biochar. The continuous extraction experiments (Figure 7) were conducted to identify the $\mathrm{P}$ desorption kinetics characteristic of postsorption $\mathrm{Mg} /$ biochar and postsorption biochar. The results indicated that magnesium nanoparticles embedded in $\mathrm{Mg} / \mathrm{biochar}$ do not affect $\mathrm{P}$ release in acid soil solution. The interval extraction experiments (Figure 8), which could simulate the situation of farm irrigation and rainwater rinse, revealed the $\mathrm{P}$ release character with repetitious elution. The results indicated postsorption $\mathrm{Mg} / \mathrm{biochar}$ could persistently release $\mathrm{P}$ as with postsorption biochar.

Figure 7. (a) continuous extraction of postsorption $\mathrm{Mg} / \mathrm{B} 300$ and postsorption $\mathrm{B} 300$; (b) continuous extraction of postsorption $\mathrm{Mg} / \mathrm{B} 450$ and postsorption $\mathrm{B} 450$; (c) continuous extraction of postsorption Mg/B600 and postsorption B600.

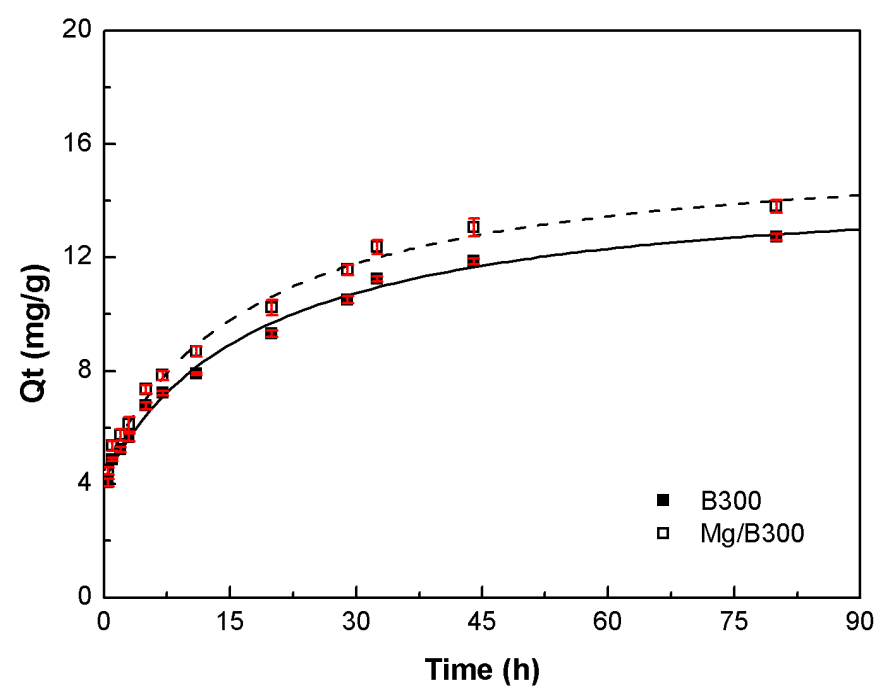

(a)

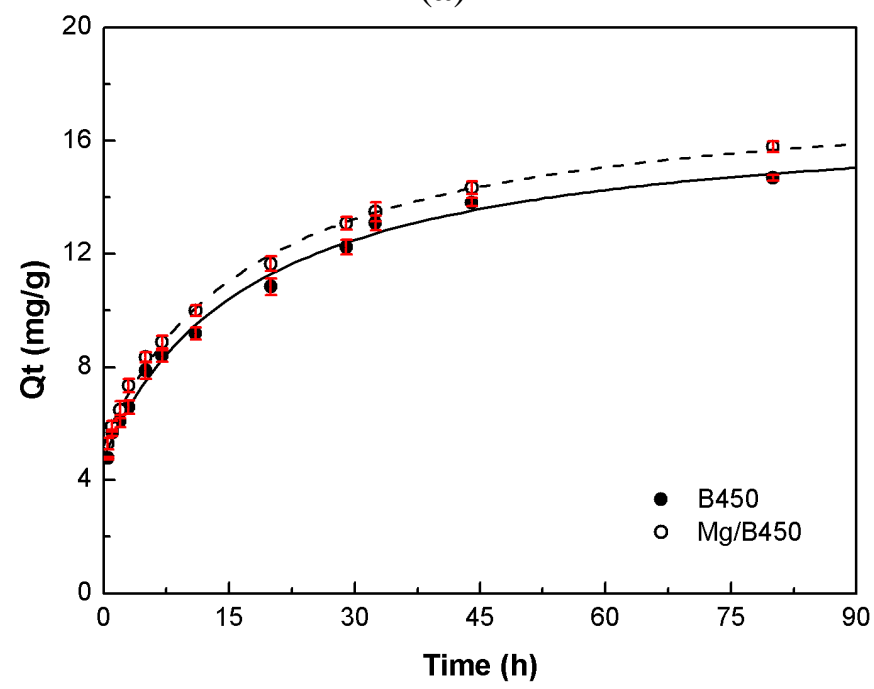

(b) 
Figure 7. Cont.

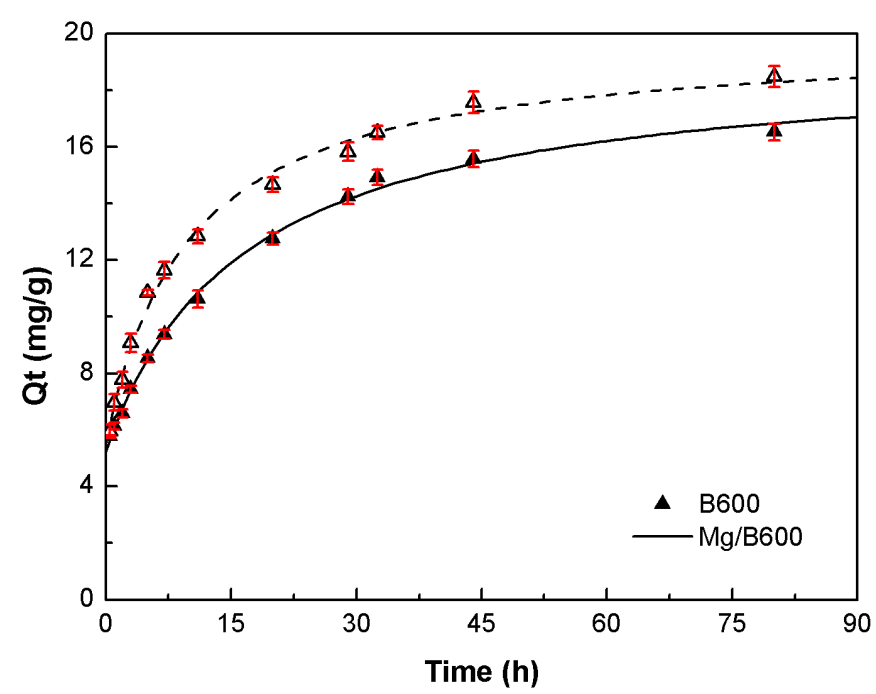

(c)

Figure 8. Interval extraction of postsorption $\mathrm{Mg} / \mathrm{biochar}$ and postsorption biochar.

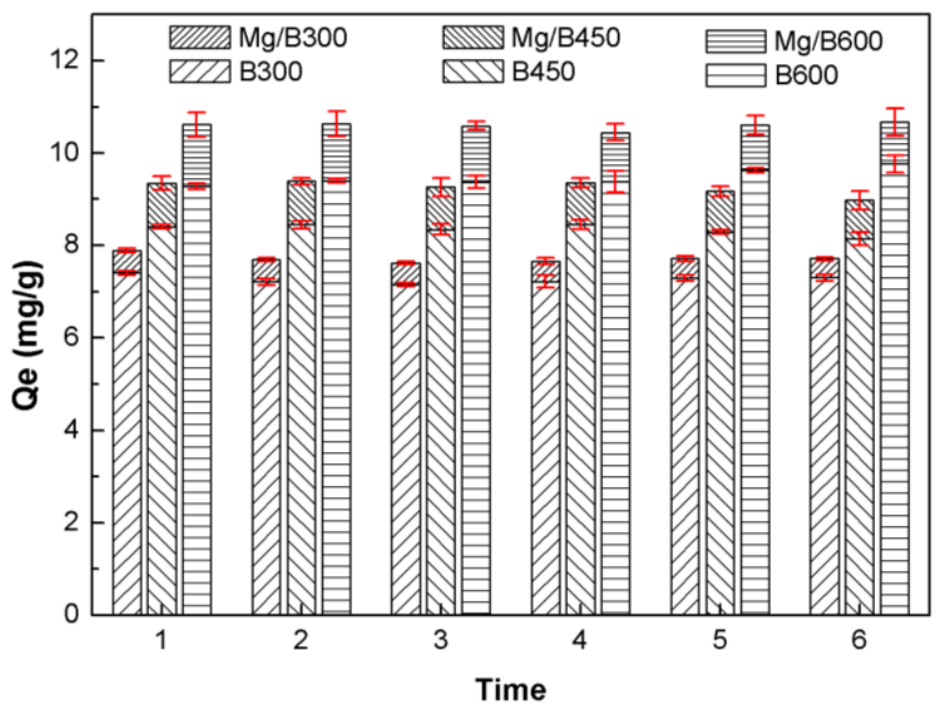

Figure 7 indicates that postsorption $\mathrm{Mg} /$ biochar, as with postsorption biochar, could gradually release $\mathrm{P}$ in citric acid DI. Thus, the embedded magnesium nanoparticles could not affect the $\mathrm{P}$ release of postsorption $\mathrm{Mg} /$ biochar in acid soil solution significantly. The pseudo second-order kinetic equation was used to describe the release process of $\mathrm{P}$ into extraction solution by postsorption $\mathrm{Mg} / \mathrm{biochar}$ and postsorption biochar as follows:

$$
\frac{t}{C_{t}}=\frac{1}{k_{d s} C_{e}^{2}}+\frac{t}{C_{e}}
$$

where $C_{t}(\mathrm{mg} / \mathrm{L})$ represents $\mathrm{P}$ concentration at $t ; C_{e}(\mathrm{mg} / \mathrm{L})$ denotes $\mathrm{P}$ concentration at release equilibrium; and, $k_{d s}\left(\mathrm{~L} \cdot \mathrm{mg}^{-1} \cdot \mathrm{h}^{-1}\right)$ indicates the kinetic constant of second-order equation. The $\mathrm{P}$ release processes of $\mathrm{Mg} /$ biochar and biochar fit the pseudo second-order kinetic model well. Moreover, the $\mathrm{P}$ release equilibrium concentrations were ordered as $\mathrm{Mg} / \mathrm{B} 600>\mathrm{Mg} / \mathrm{B} 450>\mathrm{Mg} / \mathrm{B} 300$ and B600 > B450 
$>\mathrm{B} 300$, respectively. This sequence can be attributed to the total amounts of adsorbed $\mathrm{P}$, which are ordered as $\mathrm{Mg} / \mathrm{B} 600>\mathrm{Mg} / \mathrm{B} 450>\mathrm{Mg} / \mathrm{B} 300$ and $\mathrm{B} 600>\mathrm{B} 450>\mathrm{B} 300$.

The interval extraction experiment result (Figure 8) suggests that postsorption $\mathrm{Mg} /$ biochar, as same as postsorption biochar, could persistently release $\mathrm{P}$ when the fresh citric acid DI was replaced, although the amount of $\mathrm{P}$ released was slight when the extraction solution reached equilibrium in the continuous extraction experiment. $\mathrm{Mg} / \mathrm{B} 300, \mathrm{Mg} / \mathrm{B} 450$, and $\mathrm{Mg} / \mathrm{B} 600$ could release $3.3 \%, 3.9 \%$, and $4.4 \%$ of total adsorbed P per time interval, whereas B300, B450, and B600 could release $3.6 \%, 4.1 \%$, and $4.2 \%$ of total adsorbed $\mathrm{P}$ per time interval. This result confirms that postsorption $\mathrm{Mg} /$ biochar could persistently release $\mathrm{P}$ gradually for use as slow-release fertilizer. The results obtained in our research are similar to others reported results [21].

\section{Conclusions}

The $\mathrm{Mg} /$ biochar adsorption process recovered $\mathrm{P}$ from swine wastewater was more effectively than biochar. The following conclusions can, thus, be obtained.

Numerous magnesium nanoparticles were found in $\mathrm{Mg} / \mathrm{biochar}$. Moreover, an increase in the pyrolysis temperatures of $\mathrm{Mg} /$ biochar and biochar induced a decrease in yield, an increase in C content, a decrease in $\mathrm{H}$ content, and an increase in BET surface area. $\mathrm{N}$ content does not change significantly. In addition, $\mathrm{Mg} /$ biochar and biochar were both rich in organic functional groups, such as $\mathrm{O}-\mathrm{H}, \mathrm{C}=\mathrm{O}, \mathrm{C}=\mathrm{C}$, and $\mathrm{C}-\mathrm{Cl}$.

The $\mathrm{P}$ adsorption process of $\mathrm{Mg} /$ biochar was mainly controlled by chemical action, whereas that of biochar was mainly driven by physical action. $\mathrm{Mg} /$ biochar could adsorb $90 \%$ of the equilibrium amount of $\mathrm{P}$ within $30 \mathrm{~min}$. Furthermore, the Langmuir-Freundlich model fitted the $\mathrm{P}$ adsorption isotherm of $\mathrm{Mg} /$ biochar and biochar best. Moreover, $\mathrm{Mg} /$ biochar adsorbed more $\mathrm{P}$ from swine wastewater with the maximum $\mathrm{P}$ adsorption amount of $239 \mathrm{mg} / \mathrm{g}$, while that of biochar was $225 \mathrm{mg} / \mathrm{g}$. The $\mathrm{P}$ adsorption processes of $\mathrm{Mg} / \mathrm{biochar}$ and biochar were endothermic, spontaneous, and disorderly increase process. The thermodynamics calculation formulas of $\mathrm{P}$ adsorption processes were given as $\Delta \mathrm{H}>0, \Delta \mathrm{G}<0$, and $\Delta S>0$.

The resistance of $\mathrm{Mg} /$ biochar to $\mathrm{pH}$ was stronger than that of biochar. Moreover, $\mathrm{P}$ adsorption capability of $\mathrm{Mg} / \mathrm{biochar}$ reached its maximum at $\mathrm{pH}$ 9. The selective adsorption of $\mathrm{P}$ by $\mathrm{Mg} / \mathrm{biochar}$ was stronger than that by biochar given coexisting ions. The amount of $\mathrm{P}$ adsorbed by $\mathrm{Mg} / \mathrm{B} 300$, $\mathrm{Mg} / \mathrm{B} 450$, and $\mathrm{Mg} / \mathrm{B} 600$ from swine wastewater were lower than those obtained from synthetic $\mathrm{P}$ wastewater by $6.6 \%, 4.8 \%$, and $4.2 \%$.

The $\mathrm{Mg}$ nanoparticles in $\mathrm{Mg} /$ biochar did not affect $\mathrm{P}$ release significantly. Postsorption $\mathrm{Mg} / \mathrm{biochar}$ persistently released $\mathrm{P}$, as with postsorption biochar. The $\mathrm{P}$ release equilibrium concentrations were ordered as $\mathrm{Mg} / \mathrm{B} 600>\mathrm{Mg} / \mathrm{B} 450>\mathrm{Mg} / \mathrm{B} 300 . \mathrm{Mg} / \mathrm{B} 300, \mathrm{Mg} / \mathrm{B} 450$, and Mg/B600 could release 3.3\%, $3.9 \%$, and $4.4 \%$ of total adsorbed $\mathrm{P}$ per time interval.

Although the $\mathrm{Mg}$ nanoparticles embedded in biochar may increase the cost of swine wastewater treatment, this synthetic $\mathrm{Mg} / \mathrm{biochar}$ is advantageous because of its increased P recovery efficiency and strong P selectivity. The synergistic effect of P recycling is significant for environmental, economic, and social development; therefore, $\mathrm{Mg} /$ biochar can be appropriately used to recycle $\mathrm{P}$ from swine wastewater. 


\section{Acknowledgments}

The work was supported by a grant from the National Natural Science Foundation of China (No. 31401944), the Specialized Research Fund for the Doctoral Program of Higher Education of China (20120008120013), the Beijing Municipal Natural Science Foundation (6144026), and the China Scholarship Council (201206355006).

\section{Author Contributions}

Ci Fang and Tao Zhang are responsible for the experimental research work and the paper writing work. Ping Li and Ying-cai Wang are responsible for the experimental work. Professor Rong-feng Jiang is the guidance for the research work and writing work.

\section{Conflicts of Interest}

The authors declare no conflict of interest.

\section{References}

1. China's Volatile Pork Industry. Available online: http://ers.usda.gov/media/262067/ldpm211011.pdf (accessed on February 2012).

2. Cordell, D.; Rosemarin, A.; Schroder, J.J.; Smit, A.L. Towards global phosphorus security: A systems framework for phosphorus recovery and reuse options. Chemosphere 2011, 84, 747-758.

3. Elser, J.; Bennett, E. Phosphorus cycle: A broken biogeochemical cycle. Nature 2011, 478, $29-31$.

4. Liu, Y.; Kumar, S.; Kwag, J.H.; Ra, C. Magnesium ammonium phosphate formation, recovery and its application as valuable resources: A review. J. Chem. Technol. Biotechnol. 2013, 88, 181-189.

5. Zhang, T.; Li, P.; Fang, C.; Jiang, R. Phosphate recovery from animal manure wastewater by struvite crystallization and $\mathrm{CO}_{2}$ degasification reactor. Ecol. Chem. Eng. S 2014, 21, 89-99.

6. Bektas, N.; Akbulut, H.; Inan, H.; Dimoglo, A. Removal of phosphate from aqueous solutions by electro-coagulation. J. Hazard. Mater. 2004, 106, 101-105.

7. Li, J.; Song, C.; Su, Y.; Long, H.; Huang, T.; Yeabah, T.O.; Wu, W. A study on influential factors of high-phosphorus wastewater treated by electrocoagulation-ultrasound. Environ. Sci. Pollut. Res. 2013, 20, 5397-5404.

8. Han, X.; Liang, C.F.; Li, T.Q.; Wang, K.; Huang, H.G.; Yang, X.E. Simultaneous removal of cadmium and sulfamethoxazole from aqueous solution by rice straw biochar. J. Zhejiang Univ. Sci. B 2013, 14, 640-649.

9. Kong, H.; He, J.; Gao, Y.; Wu, H.; Zhu, X. Cosorption of phenanthrene and mercury(II) from aqueous solution by soybean stalk-based biochar. J. Agric. Food Chem. 2011, 59, 12116-12123.

10. Zheng, W.; Guo, M.; Chow, T.; Bennett, D.N.; Rajagopalan, N. Sorption properties of greenwaste biochar for two triazine pesticides. J. Hazard. Mater. 2010, 181, 121-126.

11. Guo, Y.; Tang, H.; Li, G.; Xie, D. Effects of cow dung biochar amendment on adsorption and leaching of nutrient from an acid yellow soil irrigated with biogas slurry. Water Air Soil Pollut. 2014, 225, 1-13. 
12. Park, J.H.; Choppala, G.; Lee, S.J.; Bolan, N.; Chung, J.W.; Edraki, M. Comparative sorption of Pb and $\mathrm{Cd}$ by biochars and its implication for metal immobilization in soils. Water Air Soil Pollut. 2013, 224, 1-12.

13. Yao, Y.; Gao, B.; Inyang, M.; Zimmerman, A.R.; Cao, X.; Pullammanappallil, P.; Yang, L. Removal of phosphate from aqueous solution by biochar derived from anaerobically digested sugar beet tailings. J. Hazard. Mater. 2011, 190, 501-507.

14. Hale, S.E.; Alling, V.; Martinsen, V.; Mulder, J.; Breedveld, G.D.; Cornelissen, G. The sorption and desorption of phosphate-P, ammonium-N and nitrate- $\mathrm{N}$ in cacao shell and corn cob biochars. Chemosphere 2013, 91, 1612-1619.

15. Meng, S.; Li, Y.; Zhang, T.; Chen, J.; Xu, P.; Song, C.; Fan, L.; Qiu, L. Influences of environmental factors on Lanthanum/Aluminum-Modified Zeolite Adsorbent (La/Al-ZA) for phosphorus adsorption from wastewater. Water Air Soil Pollut. 2013, 224, 1-8.

16. Johan, E.; Shukla, E.A.; Matsue, N.; Henmi, T. Fe-treated artificial zeolite as an adsorbent for anionic and cationic pollutants. Procedia Environ. Sci. 2013, 17, 285-290.

17. Chen, B.; Chen, Z.; Lv, S. A novel magnetic biochar efficiently sorbs organic pollutants and phosphate. Bioresour. Technol. 2011, 102, 716-723.

18. Zhang, M.; Gao, B. Removal of arsenic, methylene blue, and phosphate by biochar/AlOOH nanocomposite. Chem. Eng. J. 2013, 226, 286-292.

19. Johnston, A.E.; Richards, I.R. Effectiveness of different precipitated phos-phates as phosphorus sources for plants. Soil Manag. 2003, 19, 45-49.

20. Rittmann, B.E.; Mayer, B.; Westerhoff, P.; Edwards, M. Capturing the lost phosphorus. Chemosphere 2011, 84, 846-853.

21. Yao, Y.; Gao, B.; Chen, J.; Yang, L. Engineered biochar reclaiming phosphate from aqueous solutions: Mechanisms and potential application as a slow-release fertilizer. Environ. Sci. Technol. 2013, 47, 8700-8708.

22. Chang, J.; Cheng, W.; Yin, Q.; Zuo, R.; Song, A.; Zheng, Q.; Wang, P.; Wang, X.; Liu, J. Effect of steam explosion and microbial fermentation on cellulose and lignin degradation of corn stover. Bioresour. Technol. 2012, 104, 587-592.

23. Novak, J.M.; Lima, I.; Xing, B.; Gaskin, J.W.; Steiner, C.; Das, K.; Ahmedna, M.; Rehrah, D.; Watts, D.W.; Busscher, W.J. Characterization of designer biochar produced at different temperatures and their effects on a loamy sand. Ann. Environ. Sci. 2009, 3, 195-206.

24. Azargohar, R.; Nanda, S.; Kozinski, J.A.; Dalai, A.K.; Sutarto, R. Effects of temperature on the physicochemical characteristics of fast pyrolysis bio-chars derived from Canadian waste biomass. Fuel 2014, 125, 90-100.

25. Gaskin, J.; Steiner, C.; Harris, K.; Das, K.; Bibens, B. Effect of low-temperature pyrolysis conditions on biochar for agricultural use. Trans. ASABE 2008, 51, 2061-2069.

26. Tang, J.; Zhu, W.; Kookana, R.; Katayama, A. Characteristics of biochar and its application in remediation of contaminated soil. J. Biosci. Bioeng. 2013, 116, 653-659.

27. Geng, W.; Nakajima, T.; Takanashi, H.; Ohki, A. Analysis of carboxyl group in coal and coal aromaticity by Fourier Transform Infrared (FT-IR) spectrometry. Fuel 2009, 88, 139-144. 
28. Venkata Mohan, S.; Chandrasekhar Rao, N.; Karthikeyan, J. Adsorptive removal of direct azo dye from aqueous phase onto coal based sorbents: A kinetic and mechanistic study. J. Hazard. Mater. 2002, 90, 189-204.

29. Tseng, R.-L.; Wu, F.-C. Inferring the favorable adsorption level and the concurrent multi-stage process with the Freundlich constant. J. Hazard. Mater. 2008, 155, 277-287.

30. Öztürk, N.; Bektaş, T.E. Nitrate removal from aqueous solution by adsorption onto various materials. J. Hazard. Mater. 2004, 112, 155-162.

31. Chand, P.; Shil, A.K.; Sharma, M.; Pakade, Y.B. Improved adsorption of cadmium ions from aqueous solution using chemically modified apple pomace: Mechanism, kinetics, and thermodynamics. Int. Biodeterior. Biodegrad. 2014, 90, 8-16.

32. Namasivayam, C.; Sangeetha, D. Equilibrium and kinetic studies of adsorption of phosphate onto $\mathrm{ZnCl}_{2}$ activated coir pith carbon. J. Colloid Interface Sci. 2004, 280, 359-365.

33. Halajnia, A.; Oustan, S.; Najafi, N.; Khataee, A.; Lakzian, A. Adsorption-desorption characteristics of nitrate, phosphate and sulfate on $\mathrm{Mg}-\mathrm{Al}$ layered double hydroxide. Appl. Clay Sci. 2013, 80, 305-312.

34. Kumar, P.; Sudha, S.; Chand, S.; Srivastava, V.C. Phosphate removal from aqueous solution using coir-pith activated carbon. Sep. Sci. Technol. 2010, 45, 1463-1470.

35. Liu, J.; Zhou, Q.; Chen, J.; Zhang, L.; Chang, N. Phosphate adsorption on hydroxyl-iron-lanthanum doped activated carbon fiber. Chem. Eng. J. 2013, 215, 859-867.

(C) 2014 by the authors; licensee MDPI, Basel, Switzerland. This article is an open access article distributed under the terms and conditions of the Creative Commons Attribution license (http://creativecommons.org/licenses/by/3.0/). 